Provided for non-commercial research and education use. Not for reproduction, distribution or commercial use.

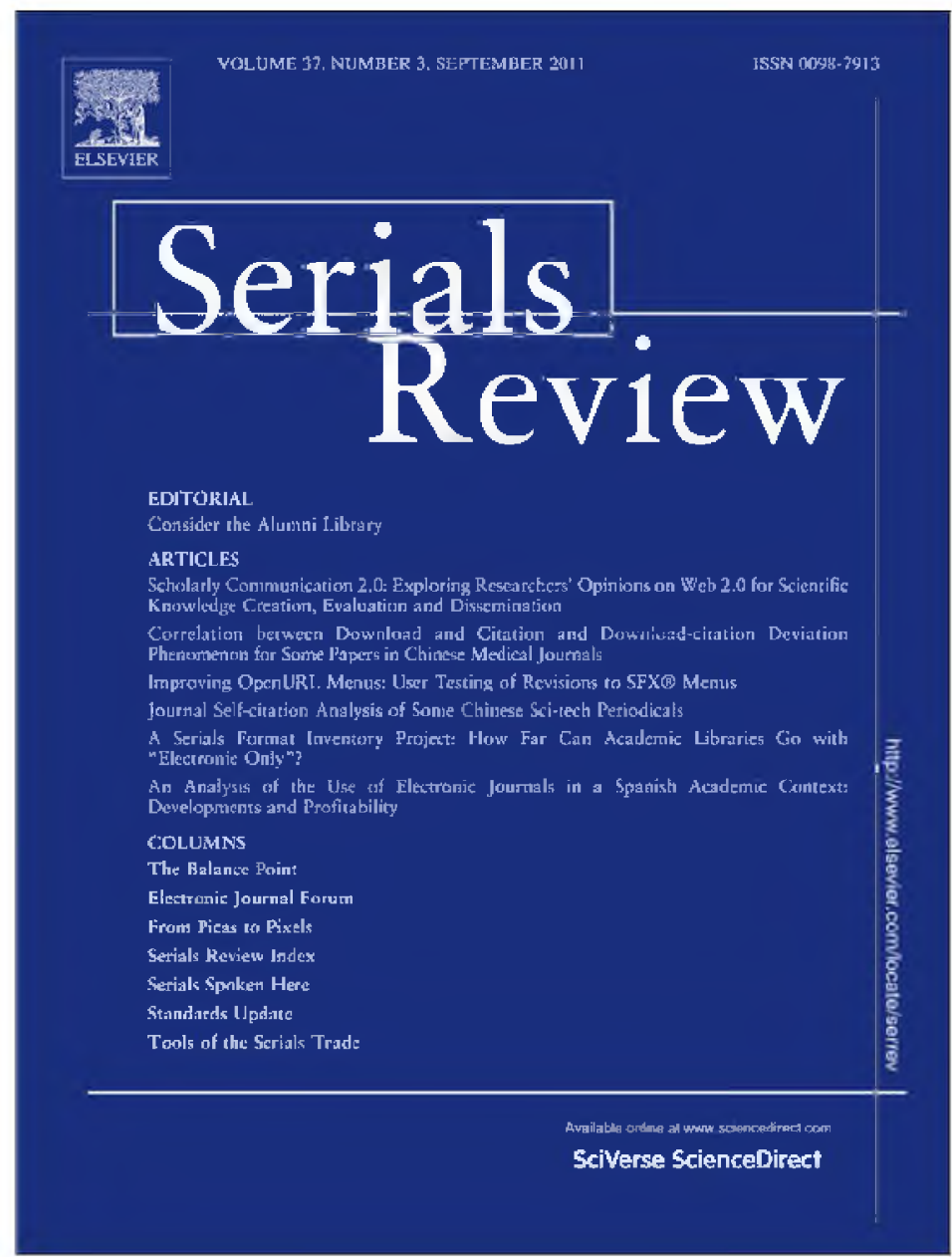

This article appeared in a journal published by Elsevier. The attached copy is furnished to the author for internal non-commercial research and education use, including for instruction at the authors institution and sharing with colleagues.

Other uses, including reproduction and distribution, or selling or licensing copies, or posting to personal, institutional or third party websites are prohibited.

In most cases authors are permitted to post their version of the article (e.g. in Word or Tex form) to their personal website or institutional repository. Authors requiring further information regarding Elsevier's archiving and manuscript policies are encouraged to visit:

http://www.elsevier.com/copyright 


\title{
An Analysis of the Use of Electronic Journals in a Spanish Academic Context: Developments and Profitability
}

\author{
Blanca Rodríguez Bravo and Ma Luisa Alvite Díez
}

Available online 4 August 2011

\begin{abstract}
This article studies the models of consumption of the academic communities of five Spanish universities with regard to the use of contents distributed by four major providers of electronic journals from the time at which subscriptions were first taken until 2010. Similarly, the authors undertook an initial approach to assess the value of the financial investment in such subscriptions on the basis of data from the Spanish universities of Leon and of Vigo. Serials Review 2011; 37:181-195.

(C) 2011 Elsevier Inc. All rights reserved.
\end{abstract}

Keywords: Spanish academic libraries; Electronic journals usage; Library subscriptions return on investment; Suppliers of electronic journals

\section{Introduction}

The work presented here is the outcome of a line of research begun in $2004^{1}$ intended to investigate the supply and use of electronic journals incorporated into university libraries through being bought as part of a package, in most instances in the form of joint purchasing. The first stages were aimed at a study of coverage of topics and the technical and functional features of the principal distributors of electronic content. As noted by Ken Eason, Sue Richardson and Liangzhi Yu, ${ }^{1}$ usage is affected by influences from content (coverage and relevance) and ease of use (Blanca Rodríguez and M. Luisa Alvite ${ }^{2,3}$ and Alvite and Rodrígue $z^{4}$ ).

The study was extended in $2006,{ }^{2}$ concentrating on an investigation of the consumption of electronic information at the point of transition from paper to digital format. It also considered future models for the development of collections in university libraries that would allow them to maintain their leading role in the provision of scholarly information.

The current intention is to analyze how the consumption of academic information evolved over the first decade of the twentyfirst century and make a first approach to judging the financial viability of the investments in these packaged electronic resources

Bravo is Assistant Professor at the Department of Library and Information Science at the University of León, Spain; e-mail: blanca.rodriguez@unileon.es.

Diez is Assistant Professor at the Department of Library and Information Science at the University of León, Spain; e-mail: luisa.alvite@unileon.es.

${ }^{1}$ A research project funded by the University of Leon into the evaluation of suppliers of e-journals and an assessment of the quality of digital publications (Reference: ULE2003-06), headed by Dr. Blanca Rodríguez Bravo.

Research projects funded by the Education Commission of the Autonomous Government of Castile and Leon. One was an investigation of the use of electronic resources in libraries, the basis for the learning model put forward for the European Higher Education Area (Reference: ULE13/05, No. 144, announced in the Regional Official Gazette [BOCYL] on 27 July 2005). The other was an analysis of the consumption of electronic information as a parameter of quality in university libraries (Reference: LE009B06, announced in BOCYL No. 143 on 26 July 2006). Both were headed by Dr. Blanca Rodríguez Bravo. from major suppliers. To this end, a collaboration agreement was drawn up and signed by the research group and by the Consortium of Libraries in Castile and Leon (BUCLE) in 2010.

This line of research can be followed up through the literature reviews undertaken by Carol Tenopir ${ }^{5}$, Ian Rowlands ${ }^{6}$ and the papers included in the proceedings of the seminar that the Ingenta Institute ${ }^{7}$ ran specifically on the topic of joint purchasing and its value. The electronic journal packages were subscribed to on the basis of the Big Deal model. This has been the subject of a number of studies that have established a reference framework: David Baker, ${ }^{8}$ David Ball, ${ }^{9}$ Ángel Borrego, ${ }^{10}$ Kenneth Frazier, ${ }^{11,12}$ David Nicholas and Paul Huntington, ${ }^{13}$ Mark Rowse, ${ }^{14}$ Thomas Sanville ${ }^{15,16}$ and Cristóbal Urbano et al. ${ }^{17}$

In the light of the studies carried out, the gains offered by the Big Deal model have been considerable, at least in relative terms. Inflationary pressures affected the price of periodicals and led libraries into cancellation after cancellation. Apart from the great increase in the accessibility of academic journals, such packaged deals provided more flexibility in the use of information, as confirmed by the universities in Ohio, where, as pointed out by Sanville, ${ }^{18}$ two-thirds of the titles used had not been previously available in paper form. This same author stressed the advantages of a growth in the number of journals available, with wider availability and accessibility of documents leading to greater use of them. Certainly a freer, more random and exploratory consumption of electronic collections implies greater spread in the use of the resources available in libraries.

This joint purchase (consortial) model is the context in which the usage of statistics on electronic resources must be set, as also any assessment of the value for money of investments or of user satisfaction. Thomas Peters summarized the usefulness of journal usage data obtained through gathering, exploiting and analyzing detailed and exhaustive statistics. ${ }^{19}$ Reasons support academic environments, motives connected with planning and evaluating library services, reasons relating to finance in the context of the internal management of consortia and participating libraries and, 
finally, motives of a financial character in the area of renegotiation of licenses.

In recent years, studies of user behavior, based on the investigation of $\log$ files and of data gathered in surveys, paralleled analyses of statistical data provided by aggregators. Of particular note is the work done by Eason, Richardson and $\mathrm{Yu}^{20}$, Eason, Yu and Susan Harker, ${ }^{21}$ Philip Davis, ${ }^{22-24}$ Davis and Leah Solla, ${ }^{25}$ Davis and Jason Price, ${ }^{26}$ Marisa Scigliano, ${ }^{27}$ and by the CIBER research group led by David Nicholas in the United Kingdom and Carol Tenopir in the United States (Paul Huntington et al. ${ }^{28}$; David Nicholas et al. ${ }^{29}$; Nicholas et al. $^{30,31}$ and Tenopir et al. ${ }^{32}$ ). In nonEnglish-speaking contexts, there are studies of note by Paola Gargiulo, ${ }^{33}$ Joseph Rogani ${ }^{34}$ and Cherifa Boukacem-Zeghmouri and Joachim Schöpel. ${ }^{35}$ In Spain, authors refer readers to work done by Borrego and Urbano, ${ }^{36}$ Borrego et al., ${ }^{37}$ Rodríguez et al., ${ }^{38}$ Miquel Termens, ${ }^{39}$ and Candela Ollé and Borrego. ${ }^{40}$

The conclusions presented in this paper refer fundamentally to the changes in patterns of use in a group of universities in northwestern Spain, these being institutions of varying sizes. They also relate to the value for money of investments in the contents distributed by four of the principal suppliers of electronic journals.

Assessments are essential if progress is to be made in shaping an adequate infrastructure that will guarantee access to scientific and technical information. Such evaluations must be based on the application of techniques and methods that allow reliable information to support decision-making for purchasing subscriptions and safeguarding the investment of limited budgets.

\section{Objectives}

The overall objective of the work was to learn the preferences and models of consumption of the academic communities of five Spanish universities regarding the use of journal content distributed by four major providers, from the time at which subscriptions were first taken out until 2010. Similarly, an initial approach was to be made in assessing the value for money of the financial investment made in such subscriptions on the basis of data from the universities of Leon and of Vigo.

Specifically, the authors studied the use of journals subscribed to within the packages offered by Emerald $\AA$, ScienceDirect ${ }^{\circledR}$, SpringerLink ${ }^{\circledR}$ and Wiley ${ }^{\circledR}$ at the universities of Burgos, Leon, Salamanca, Valladolid and Vigo.

The particular aims pursued were the following:

- To analyze the concentration and/or dispersion of use of the electronic contents for which subscriptions were held.

- To inquire as to the preferences of the various universities concerned, evaluating the differences in the use made of electronic contents by five universities in the North-West of Spain.

- To reach conclusions with respect to the relevance of the four packages of e-journals that are most widely used.

- To investigate the value for money of subscriptions to electronic contents.

- To assess developments in the consumption of electronic information over the first decade of the twenty-first century.

- To determine the strengths and weaknesses of the model of subscriptions to fixed packages, or the Big Deal.

\section{Methodology}

\section{Institutions Investigated}

As noted above, the universities studied were those of Burgos, Leon, Salamanca, Valladolid and Vigo. The first four of these are state universities in the Castile and Leon Autonomous Region and
Table 1. Data on universities

\begin{tabular}{lccccc}
\hline University & Students & & & \multicolumn{2}{c}{ Academic staff } \\
\cline { 2 - 3 } \cline { 6 - 6 } \cline { 5 - 6 } & $\mathbf{2 0 0 5 - 2 0 0 6}$ & $\mathbf{2 0 0 9 - 2 0 1 0}$ & & $\mathbf{2 0 0 5 - 2 0 0 6}$ & $\mathbf{2 0 0 9 - 2 0 1 0}$ \\
\hline Burgos & 9,062 & 7,445 & & 653 & 694 \\
Leon & 15,568 & 11,874 & & 941 & 987 \\
Salamanca & 32,140 & 26,135 & & 2,306 & 2,709 \\
Valladolid & 30,939 & 25,218 & & 2,461 & 2,497 \\
Vigo & 26,005 & 20,709 & & 1,536 & 1,611 \\
\hline
\end{tabular}

form the BUCLE consortium, while the University of Vigo is one of the three state universities in the Autonomous Region of Galicia and forms part of the Bugalicia consortium.

These institutions are of varying sizes. The figures for teaching and research staff and for students in all the universities considered are as shown below, ${ }^{3,4}$ (table 1 ).

The University of Burgos is the smallest institution, the next in size being the University of Leon. The other two universities in Castile and Leon both have more than 25,000 students, the University of Vigo coming close to this figure.

Between 2005 and 2009 these five universities had a stable total number of research and teaching staff with the exception of the University of Salamanca, which saw a slight increase. Student numbers, however, reflected a significant decrease.

The official figures for the total numbers of degree programs offered date from before the start of the phase of introduction of Undergraduate and Post-Graduate studies adapted to the European Higher Education Area, which lasted from the academic year 2006-2007 until 2010-2011. This situation has inevitably led to some overlapping of syllabuses, which makes it difficult to give reliable data for recent years.

Table 2 shows the number of degree programs offered by each university, subdivided into the five main areas of education, as also the percentage of the total courses available. The field with the largest presence among the degree programs offered by the group of universities under consideration was the area of social sciences, followed by the block bringing together technical degrees.

Burgos was the most specialized university, having 50 percent of its degree programs in social sciences and more than 30 percent technical degree courses. Valladolid followed a similar trend. Health sciences had a significant weighting in Leon, while Burgos and Vigo were at the opposite end of the spectrum, with just one program each in this field. Courses in experimental sciences were more strongly represented at Salamanca, Valladolid and Vigo.

The humanities had considerable representation at all the universities except Burgos, where there was just one program in this area. Salamanca, historically specializing in this field, had twenty-one programs related to languages, history and literature.

\section{Data Processing and Analysis}

The period considered runs from the beginning of joint purchasing of electronic resources, which goes back to 2002 down to 2009 .

As the subscription periods are not identical for all the packages in all the universities, not all of them cover the period in question completely. Some institutions have data only from 2003 or 2004 on, while other universities lack figures for 2006 . For the early

\footnotetext{
${ }^{3}$ Hernández Armenteros, J. (ed.) (2006). La universidad española en cifras 2006 Información académica, productiva y financiera de las universidades españolas. Indicadores universitarios, curso acadèmico 2004/2005. http://www.crue.org/export/ sites/Crue/Publicaciones/Documentos/UEC/UEC2006.pdf

${ }^{4}$ Statistics for the academic year 2008 to 2009 from the Spanish Ministry of Education. http://www.educacion.es/educacion/universities/estadisticas-informes/ estadisticas.html
} 
Table 2. Programs offered

\begin{tabular}{|c|c|c|c|c|c|c|c|c|c|c|}
\hline \multirow[t]{2}{*}{ University } & \multicolumn{2}{|c|}{ Humanities } & \multicolumn{2}{|c|}{ Social sciences } & \multicolumn{2}{|c|}{ Experimental sciences } & \multicolumn{2}{|c|}{ Health sciences } & \multicolumn{2}{|c|}{ Technological subjects } \\
\hline & Degrees & Percent. & Degrees & Percent. & Degrees & Percent. & Degrees & Percent. & Degrees & Percent. \\
\hline Burgos & 1 & $3.33 \%$ & 15 & $50 \%$ & 2 & $6.67 \%$ & 1 & $3.33 \%$ & 11 & $36.67 \%$ \\
\hline Leon & 6 & $11.11 \%$ & 21 & $38.89 \%$ & 4 & $7.41 \%$ & 7 & $12.96 \%$ & 16 & $29.63 \%$ \\
\hline Salamanca & 21 & $26.58 \%$ & 24 & $30.38 \%$ & 9 & $11.39 \%$ & 6 & $7.59 \%$ & 19 & $24.05 \%$ \\
\hline Valladolid & 12 & $12.90 \%$ & 41 & $44.09 \%$ & 8 & $8.60 \%$ & 5 & $5.38 \%$ & 27 & $29.03 \%$ \\
\hline Vigo & 6 & $12.24 \%$ & 24 & $48.98 \%$ & 5 & $10.20 \%$ & 1 & $2.04 \%$ & 13 & $26.53 \%$ \\
\hline
\end{tabular}

years in which there were subscriptions, only overall download figures are taken into account.

From 2005 onward, this being the year in which a sufficient degree of consolidation of the use of electronic publications was noted throughout the group of universities, the figures become more detailed, with data on downloads per title. The data used in calculations were those provided by suppliers of e-journals to each of the libraries studied. ${ }^{5}$ These are in the form of annual Excel files with monthly figures for downloads of full-text articles, broken down by titles of journals. From these, the exact amount of use made of the package supplied by each publisher was calculated. The universities of Leon and Vigo provided prices for licenses information

The following is a list of performance indicators organized into several levels or groupings:

1. Data on overall downloads broken down by institution and by year.

- Articles downloaded by each institution annually.

- Articles downloaded by supplier and by institution annually.

2. The ratios of articles downloaded: academic years 2005-2006 and 2009-2010.

- Ratio of total downloads to faculty by institution.

- Ratio of downloads per 1000 students and by institution/ distributor.

- Ratio of downloads per 100 academic staff and by institution/ distributor.

3. Data on titles used broken down by supplier and by institution in 2006 and 2009.

- Titles subscribed to by provider and by institution.

- Titles used by supplier and by institution.

- Core titles by provider and by institution.

- Dispersion and concentration of use by supplier and by institution.

The threshold used in establishing which titles constituted the core was a total of ten or more downloads. The ratio between titles used and titles subscribed to yields the dispersion rate for any provider. The ratio between core titles and titles used gives the concentration rate for use.

4. Financial data

- Evolution of costs of packages.

- Cost per title subscribed to.

- Cost per title used.

- Cost per core title.

- Cost per article downloaded.

- Cost per 1000 students.

- Cost per 100 academics

\footnotetext{
${ }^{5}$ These data were taken from the Excel files directly supplied by the libraries studied. The authors wish to express their thanks to the Head Librarians of each of them and to the librarians responsible for the Periodicals Service for their collaboration. The BUCLE consortium has acquired the tool SwetsWise Selection Support, but at the point in time when this study was carried out this did as not yet contain the information required for an analysis of the sort being presented here.
}

- Assessment of return on investment made.

- Assessment of gains from the Big Deal model.

\section{Results and Discussion}

\section{Data for Overall Downloads of Articles Broken Down by Institution and Ratios of Articles per Students and Academic Staff}

Details of the annual downloads made by each institution are presented in table 1 , which is included in Appendix A. The data for the University of Valladolid between 2002 and 2005 do not include figures for downloads from Wiley because the university did not subscribe to that package until April 2005. In the case of the University of Burgos, figures for downloads from ScienceDirect are not available for 2003 , which leads to an apparent considerable drop in the total number of downloads. When figures for downloads from at least three suppliers could not be obtained, a blank is left in the table. The details for Leon for 2006 incorporate only six months of downloads from SpringerLink, specifically from January through June.

If the data for 2005 are taken as a baseline, this being the year in which the transition phase from subscriptions in paper format to subscription in electronic form was completed, and a comparison is made with the data for 2009 , it can be observed that overall downloads increased in general terms. There was a significant growth in downloads at the University of Vigo, in particular during 2008 and 2009. A more moderate increase was to be observed in downloads at the universities of Burgos and Valladolid. A certain stability may be noted for Salamanca and for Leon; at the latter, there was in addition a curious upward blip in downloads in 2008 in comparison with 2007 and 2009

Consideration of the last four years, in which it is possible to see consolidation of the situation of e-journals among the academic community, suggests that there would appear to be three types of outcomes. In one case, the University of Vigo, there was a striking increase in the number of downloads, particularly in 2008 and 2009. In another, the universities of Burgos and Valladolid showed a tendency towards growth in consumption, but only moderately so. The third instance was the observed trend to stable levels of use of academic journals at the universities of Leon and Salamanca. (See figure 1.)

The overall numbers of faculty remained fairly stable between 2005 and 2009 in all the universities considered, with very slight increases here and there, the growth being of significance only at the University of Salamanca. With this fact in mind, it is possible to point to a tendency towards growth in the consumption of information per member of academic staff in most instances. It is especially striking what an increase there was in the consumption of electronic information among the academic community in the University of Vigo. The figures for Burgos were not negligible either. 


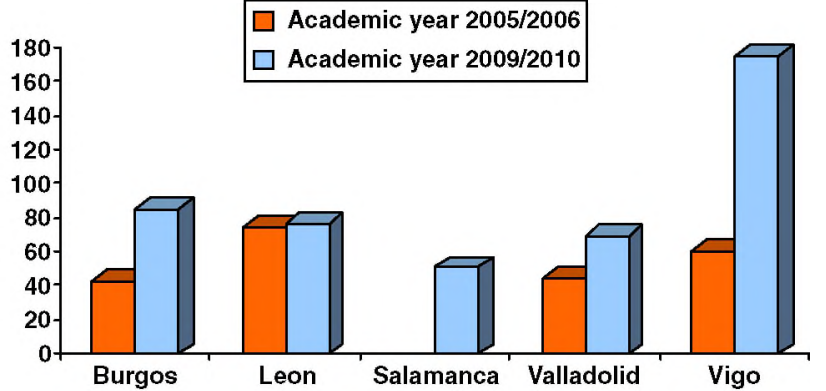

Figure 1. Ratio of downloads to academic staff by institutions.

In the case of Leon, there was a high level of downloads per academic staff member in the academic year 2005-2006, followed by stability in consumption. Its ratios were slightly higher than those of Salamanca and Valladolid for the final period analyzed. (See table 3.)

An upward trend may be observed in the figures recorded in all the institutions for which data were available. The rates of use at Vigo increased threefold and those for Burgos doubled between the two academic years analyzed. Growth in Leon and Valladolid was more modest.

The rates of use for 2009 show a high level of use of the collections subscribed to in the case of the University of Vigo; the benefits of the Big Deal model for small universities would appear undeniable. The figures for the University of Burgos are striking in light of the fact that only 10 percent of its programs are in the areas of experimental and health sciences, which are the fields with the largest amount of contents in the packages under consideration. The University of Salamanca had lower usage rates. These are likely to be an outcome of the major presence there of courses in the humanities, contents relating to which are marginal in the packages investigated, and to extensive technical degree programs, likewise limited in their representation in the offerings of these suppliers.

With regard to the details of annual downloads by institution and supplier, tables 2 to 5, which are included in Appendix A, should be consulted.

\section{Emerald}

Emerald is a provider specializing in social sciences, particularly in education, economics and business management. Hence its content aims at a limited range of potential users.

Taking the baseline of 2005, use of this package in Burgos, Leon and Vigo doubled in the last few years. Irregular use may be observed in Valladolid, with a drop over recent years at the University of Salamanca, a drop which may also be seen in Burgos in comparison with the data for 2007.

In respect of the proportion of downloads relative to the size of institutions, Burgos shows a clear liking for this distributor, with a total number of downloads greater than that of the larger University of Leon and comparable with those for Salamanca and Valladolid. The use made of this provider by the University of Vigo stands out in both absolute and relative terms. (See table 4.)

The figures for the use of this provider increased in all the institutions studied, with the rates in 2009 for Burgos, Vigo and Leon being particularly striking as the two largest universities made only a token consumption of the contents from this publisher.

The clear preference at the University of Burgos for contents from Emerald seems likely to be linked to the fact, already noted above, that 50 percent of its degree programs were in the field of social sciences, the area with the greatest representation among the journals distributed by this supplier. This same state of affairs appears to apply to the University of Vigo. For its part, Salamanca, the university with the lowest rates of usage, was also the institution teaching the smallest number of courses in the social sciences.

\section{ScienceDirect}

A multidisciplinary supplier run by Elsevier, which principally distributes titles in the natural and health sciences areas. It also has a significant volume of contents in pure and applied sciences, and in social sciences.

The figures for the use of this supplier are large, in accordance with the quantity and quality of contents in the package. This feature coincides with the trends observed at other universities, for instance the libraries making up the OhioLINK consortium (Sanville ${ }^{41,42}$ ), university libraries in Galicia (Bugalicia ${ }^{43}$ ) or Catalonia (Lluis Anglada et al. ${ }^{44}$; Borrego ${ }^{45}$ ).

Over the course of the decade, an extraordinary increase may be seen in the number of downloads at the universities of Burgos, Valladolid and Vigo. Nonetheless, the figures for Burgos would seem to have stabilized, while at the University of Vigo growth was apparently still continuing.

As for the University of Leon, acceptance of this package from Elsevier was noteworthy from the very beginning. Nevertheless, growth in use over the decade was more moderate than it was in the universities previously mentioned.

The University of Vigo made very intensive use of the ScienceDirect package, with figures for downloads much higher than in the universities in Castile and Leon. It is also noteworthy to what degree the academic community in Valladolid made use of this package.

There were certain noticeable peaks, for instance, at the University of Salamanca in 2006 and in Leon in 2008 . These figures had an impact on the overall growth of downloads at these institutions in the years in question, as ScienceDirect was the preferred supplier for all the universities, as may be seen from the graph below. (See table 5.)

Changes in the rate of downloading from ScienceDirect followed an upwards trend in all the universities for which data were

Table 3. Overall downloads and ratios for students and academics

\begin{tabular}{|c|c|c|c|c|c|c|}
\hline \multirow[t]{2}{*}{ University } & \multicolumn{3}{|c|}{ Academic year 2005-2006 } & \multicolumn{3}{|c|}{ Academic year 2009-2010 } \\
\hline & Total downloads & Rate per 1000 students & Rate per 100 academics & Total downloads & Rate per 1000 students & Rate per 100 academics \\
\hline Burgos & 28,218 & $3,113.8$ & $4,321.2$ & 59,437 & $7,983.4$ & $8,564.4$ \\
\hline Leon & 70,337 & $4,518.0$ & $7,474.7$ & 75,223 & $6,335.1$ & $7,621.3$ \\
\hline Salamanca & - & - & - & 137,504 & $5,261.2$ & $5,075.8$ \\
\hline Valladolid & 110,152 & $3,560.2$ & 4.475 .9 & 173,434 & $6,877.3$ & $6,945.6$ \\
\hline Vigo & 93,283 & $3,587.1$ & $6,073.1$ & 281,222 & $13,579.6$ & $17,456.3$ \\
\hline
\end{tabular}


Table 4. Emerald downloads and ratios for students and academics

\begin{tabular}{|c|c|c|c|c|c|c|}
\hline \multirow[t]{2}{*}{ University } & \multicolumn{3}{|c|}{ Academic year 2005-2006 } & \multicolumn{3}{|c|}{ Academic year 2009-2010 } \\
\hline & Total downloads & Rate per 1000 students & Rate per 100 academics & Total downloads & Rate per 1000 students & Rate per 100 academics \\
\hline Burgos & 443 & 48.8 & 67.8 & 1,106 & 148.5 & 159.3 \\
\hline Leon & 567 & 36.4 & 60.2 & 1,071 & 90.1 & 108.5 \\
\hline Salamanca & - & - & - & 1,148 & 43.9 & 42.3 \\
\hline Valladolid & 1,000 & 32.3 & 40.6 & 1,513 & 59.9 & 60.5 \\
\hline Vigo & 950 & 36.5 & 61.8 & 1,924 & 92.9 & 119.4 \\
\hline
\end{tabular}

Table 5. ScienceDirect downloads and ratios for students and academics

\begin{tabular}{|c|c|c|c|c|c|c|}
\hline \multirow[t]{2}{*}{ University } & \multicolumn{3}{|c|}{ Academic year $2005-2006$} & \multicolumn{3}{|c|}{ Academic year 2009-2010 } \\
\hline & Total downloads & Rate per 1000 students & Rate per 100 academics & Total downloads & Rate per 1000 students & Rate per 100 academics \\
\hline Burgos & 22,008 & $2,428.6$ & $3,370.2$ & 48,417 & $6,503.2$ & $6,976.5$ \\
\hline Leon & 62,658 & $4,024.7$ & $6,658.6$ & 62,121 & $5,231.6$ & $6,293.9$ \\
\hline Salamanca & - & - & - & 93,154 & $3,564.3$ & $3,438.6$ \\
\hline Valladolid & 101,954 & $3,295.3$ & $4,142.7$ & 144,433 & $5,727.3$ & $5,784.2$ \\
\hline Vigo & 77,552 & $2,982.1$ & $5,048.9$ & 239,325 & $11,556.5$ & $14,855.6$ \\
\hline
\end{tabular}

available. However, this was particularly true of the University of Vigo. Here the rates per student and per academic were highest despite the fact that natural and health sciences constituted just 12 percent of the total programs taught at this institution.

Thus, the number of articles from ScienceDirect downloaded per academic at the University of Vigo in the academic year 20092010 came close to 150 , while at the University of Salamanca this figure was limited to thirty-five. This may to some extent be an outcome of the fact that this university did not show so marked a preference for the package in question. The other three institutions had intermediate figures of around sixty downloads. Hence, the University of Salamanca was the institution having the least preference for this distributor. At the University of Leon a tendency towards stability in the rates presented was to be seen.

According to the CIBER study, ${ }^{47}$ which investigated the Elsevier package during the academic year 2006-2007 in ten institutions undertaking research in the United Kingdom, the average number of downloads per researcher was 47 articles. This figure is close to what was observed in Salamanca and was exceeded by the remaining universities considered in this work.

The downloads for the year 2009 are here employed as an example to show the volume of articles downloaded from titles distributed by Elsevier among overall downloads as a whole, relative to the other providers considered here: Emerald, SpringerLink and Wiley. (See figure 2).

In almost all the universities, downloads from ScienceDirect represented a percentage in excess of 80 percent, with Vigo having 85 percent of the grand total. The one exception was the University of Salamanca, where there was a relatively intense use of journals distributed by the other suppliers, with downloads from ScienceDirect representing 67.74 percent in this instance.

These data are in agreement with the findings of BoukacemZeghmouri $^{46}$ for France. They found that use of the Elsevier package came to 78 percent of the total of downloads.

The predominance of ScienceDirect in the overall volume of consumption in all the institutions was incontestable. The data for overall downloads per academic staff member depended strikingly upon this provider.

\section{SpringerLink}

This is a multidisciplinary provider with contents ranging over sciences, biology and medicine, chemistry, environmental studies, physics, law and economics, engineering, and other fields. This provider has had a very wide spread of contents ever since it completed its merger with Kluwer in April 2005.

In comparison with the data for ScienceDirect, the overall figures for downloads from this supplier were modest. However, they did, in general, show an upward trend. As noted above, in February 2005, Springer and Kluwer merged. This event is reflected in the totals recorded and an increase in downloads in all the institutions in 2005 , especially in Valladolid where they nearly doubled.

The growth in the figures for recent years in Salamanca and Vigo is of significant note, these being the two universities that make most intensive use of this package. Growth at Leon and Valladolid was likewise not negligible. Burgos would seem to show a tendency toward stability (See table 6.)

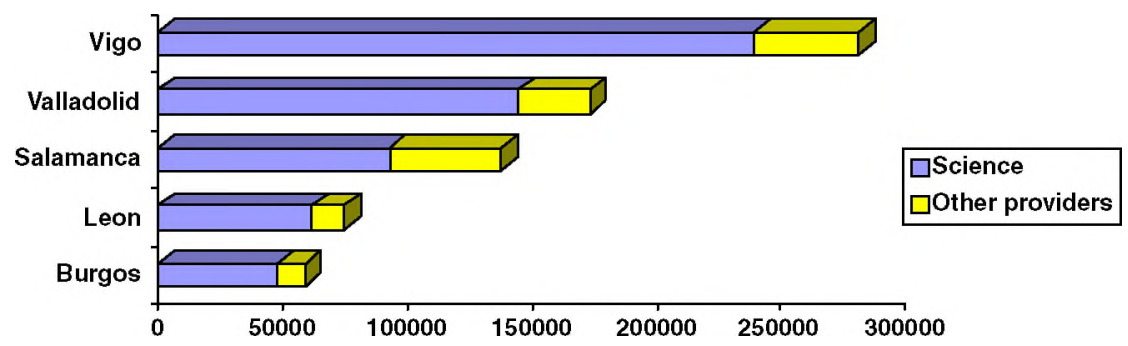

Figure 2. Downloads from ScienceDirect as a proportion of total downloads in 2009. 
Table 6. SpringerLink downloads and ratios for students and academics

\begin{tabular}{|c|c|c|c|c|c|c|}
\hline \multirow[t]{2}{*}{ University } & \multicolumn{3}{|c|}{ Academic year 2005-2006 } & \multicolumn{3}{|c|}{ Academic year 2009-2010 } \\
\hline & Total downloads & Rate per 1000 students & Rate per 100 academics & Total downloads & Rate per 1000 students & Rate per 100 academics \\
\hline Burgos & 1,330 & 146.7 & 203.6 & 3,700 & 496.9 & 533.1 \\
\hline Leon & 2,962 & 190.2 & 314.7 & 7,349 & 618.9 & 744.5 \\
\hline Salamanca & - & - & - & 20,932 & 800.9 & 772.6 \\
\hline Valladolid & 7,198 & 232.6 & 292.4 & 15,066 & 597.4 & 603.3 \\
\hline Vigo & 5,631 & 216.5 & 366.6 & 22,350 & $1,079.2$ & $1,387.3$ \\
\hline
\end{tabular}

At the universities of Burgos, Leon and Valladolid rates doubled. In the case of Vigo there was a quadrupling of the rate of usage by academics. This was the provider in respect of which the rates of use by academics were most similar among all the institutions investigated.

\section{Wiley}

This is a multidisciplinary provider with which the universities under consideration have contracts for a limited number of titles. It distributes principally journals in the social sciences, pure and applied sciences, health sciences and natural sciences, having no contents in the humanities.

In relation to the figures for overall downloads from this provider, the situation was similar to what was described for SpringerLink. The number of downloads from this source was considerably lower than from ScienceDirect.

As may be seen from table 5 in Appendix A, it is of note how the use made of this resource by the University of Vigo grew between 2005 and 2009. All the same, the University of Salamanca remained the most intensive user of this supplier and appeared to show an upward trend. The University of Burgos also showed some preference for this provider. Nonetheless, as in the remaining universities, figures for use showed clear stability in consumption over the last few years (table 7).

The preference of Burgos and Salamanca for Wiley over Springer can be seen. The remaining universities had a stronger liking for the contents distributed by SpringerLink. Changes in rates of usage were upwards.

To sum up, the data for the use made of SpringerLink and Wiley, multidisciplinary providers, are not comparable with the figures for the Elsevier package. Nonetheless, it can be pointed out that the universities of Leon, Valladolid and Vigo also showed some preference for the content distributed by SpringerLink, while Burgos and Salamanca made greater use of the package from Wiley. The data for Emerald corresponded to the very nature of a package with specialized contents, aimed at a restricted group of users. Nonetheless, usage rates at Burgos for this provider were considerable, with the large numbers of students and academics in the social sciences at this institution.

Data on Titles Used, Organized by Supplier and by Institution for 2006 and 2009.

The literature on the consumption of electronic information confirms that a limited group of journals attract a high percentage of total use. Nonetheless, it has also been observed that ease of access to a wide range of titles encourages more dispersed and flexible consumption.

As was indicated in the section on the methods employed, the threshold used in establishing which titles constituted the core was a total of ten or more downloads each year. The ratio between titles used and titles subscribed to yields the dispersion rate for any provider. The ratio between core titles and titles used gives the concentration rate for use.

The following tables, organized by providers, present titles subscribed to and titles which received some use. They also show the priority titles that constitute a core for users and dispersion and concentration rates. The tables appear first, followed by brief narrative.

\section{Emerald}

Both dispersion and concentration decreased in all the universities between 2006 and 2009. This may correspond to the increased number of titles subscribed to in the five universities, rather than to any decrease in titles used, which was noted only in Burgos, and there only to a minimal extent. In respect of the journals most intensively used, a slight general decline in the concentration rate may be seen.

The three largest universities showed similar behaviors in their use of contents from Emerald, reaching concentration rates greater than 30 percent in the two years analyzed.

\section{ScienceDirect}

A considerable percentage of the package was used, exceeding 50 percent in all the universities, and the core was much larger than in the case of the other packages analyzed. Evolution over the first half of the decade showed growth, when the data, available from Burgos, Leon and Vigo since their first contracts with the provider, were considered (Rodríguez et al. ${ }^{48}$ ).

Dispersion in Salamanca, Valladolid and Vigo was greater than 70 percent in 2009. However, in Vigo there was a slight decline regarding 2006, a situation also noted in Burgos, which may be an outcome of the striking increase in the number of titles on offer. Nevertheless, dispersion and concentration rates appeared to remain fairly stable in each of the universities in the years considered.

Table 7. Wiley downloads and ratios for students and academics

\begin{tabular}{|c|c|c|c|c|c|c|}
\hline \multirow[t]{2}{*}{ University } & \multicolumn{3}{|c|}{ Academic year 2005-2006 } & \multicolumn{3}{|c|}{ Academic year 2009-2010 } \\
\hline & Total downloads & Rate per 1000 students & Rate per 100 academics & Total downloads & Rate per 1000 students & Rate per 100 academics \\
\hline Burgos & 4,437 & 489.6 & 679.4 & 6,214 & 834.6 & 895.3 \\
\hline Salamanca & - & - & - & 22,270 & 852.1 & 822.0 \\
\hline Valladolid & - & - & - & 12,422 & 492.5 & 497.4 \\
\hline Vigo & 9,150 & 351.8 & 595.7 & 17,623 & 850.9 & $1,093.9$ \\
\hline
\end{tabular}




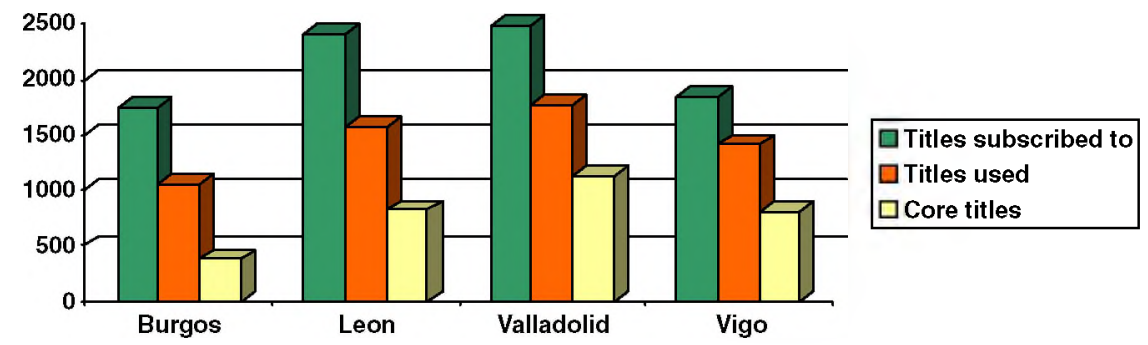

Figure 3. Titles from ScienceDirect by university in 2006.

Table 8. Emerald

\begin{tabular}{|c|c|c|c|c|c|c|c|c|c|c|}
\hline & \multicolumn{2}{|l|}{ Burgos } & \multicolumn{2}{|l|}{ Leon } & \multicolumn{2}{|c|}{ Salamanca } & \multicolumn{2}{|c|}{ Valladolid } & \multicolumn{2}{|l|}{ Vigo } \\
\hline & 2006 & 2009 & 2006 & 2009 & 2006 & 2009 & 2006 & 2009 & 2006 & 2009 \\
\hline Titles subscribed to & 193 & 264 & 157 & 271 & 193 & 271 & 139 & 272 & 193 & 272 \\
\hline Titles used & 112 & 107 & 96 & 131 & 140 & 149 & 139 & 142 & 129 & 146 \\
\hline Core titles & 30 & 23 & 25 & 33 & 58 & 56 & 60 & 47 & 50 & 55 \\
\hline Dispersion rate & $58.03 \%$ & $40.53 \%$ & $61.14 \%$ & $48.33 \%$ & $72.53 \%$ & $54.98 \%$ & $100 \%$ & $52.20 \%$ & $66.83 \%$ & $53.67 \%$ \\
\hline Concentration rate & $26.78 \%$ & $21.49 \%$ & $26.04 \%$ & $25.19 \%$ & $41.42 \%$ & $37.58 \%$ & $43.16 \%$ & $33.09 \%$ & $38.75 \%$ & $37.67 \%$ \\
\hline
\end{tabular}

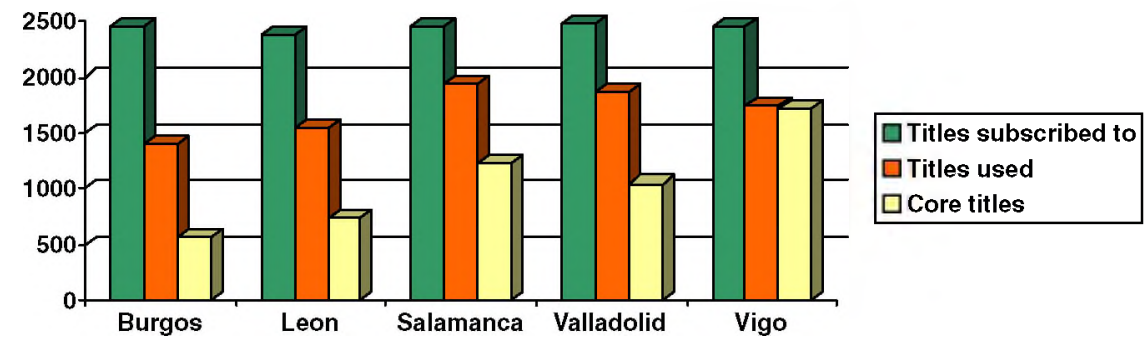

Figure 4. Titles from ScienceDirect by university in 2009.

Table 9. ScienceDirect

\begin{tabular}{|c|c|c|c|c|c|c|c|c|c|c|}
\hline & \multicolumn{2}{|l|}{ Burgos } & \multicolumn{2}{|l|}{ Leon } & \multicolumn{2}{|c|}{ Salamanca } & \multicolumn{2}{|c|}{ Valladolid } & \multicolumn{2}{|l|}{ Vigo } \\
\hline & 2006 & 2009 & 2006 & 2009 & 2006 & 2009 & 2006 & 2009 & 2006 & 2009 \\
\hline Titles subscribed to & 1752 & 2456 & 2424 & 2386 & - & 2459 & 2497 & 2468 & 1840 & 2446 \\
\hline Titles used & 1062 & 1402 & 1584 & 1542 & - & 1938 & 1769 & 1857 & 1415 & 1752 \\
\hline Core titles & 378 & 560 & 825 & 744 & - & 1236 & 1138 & 1044 & 805 & 1710 \\
\hline Dispersion rate & $60.61 \%$ & $57.08 \%$ & $65.34 \%$ & $64.62 \%$ & - & $78.81 \%$ & $70.84 \%$ & $75.24 \%$ & $76.90 \%$ & $71.62 \%$ \\
\hline Concentration rate & $35.59 \%$ & $39.94 \%$ & $52.08 \%$ & $48.24 \%$ & - & $63.77 \%$ & $64.33 \%$ & $56.21 \%$ & $56.89 \%$ & $97.60 \%$ \\
\hline
\end{tabular}

Only Vigo saw a significant increase in core titles in 2009 with regard to 2006 , leading to an extraordinarily high concentration rate of 97.60 percent. The opposite end of the scale was found in the University of Burgos with a concentration rate that did not reach 40 percent. (See figures 3 and 4 .)

\section{SpringerLink}

No intensive use of SpringerLink was observed in any of the universities. Salamanca, Valladolid and Vigo were the universities using the largest number of titles from this supplier. The dispersion rates above 50 percent in 2009 in Valladolid and Vigo, which had the smallest number of titles subscribed to, were of note. In contrast, in Salamanca, the number of titles subscribed to increased considerably from 2006 , leading to a drop in dispersion and concentration rates.
The concentration of use in Salamanca, Valladolid and Vigo was striking, with cores of titles greater than those in Burgos and Leon. However, in Leon a certain upward trend could be observed.

\section{Wiley}

The number of titles subscribed to increased notably in Burgos and Salamanca in 2009. Moderate growth in the number of titles used and in core titles was seen in all the universities except Salamanca, where growth was considerable.

Valladolid and Vigo utilized more than 50 percent of the titles to which they had subscribed and their concentration rates for use also were close to 50 percent. Regarding the number of titles subscribed to, Valladolid, Vigo and Leon appeared to take better advantage of their subscriptions than did Burgos. (Figures 5 and 6 ).

To sum up, with regard to dispersion rates, it is possible to single out the wide range of titles from ScienceDirect used over the whole 

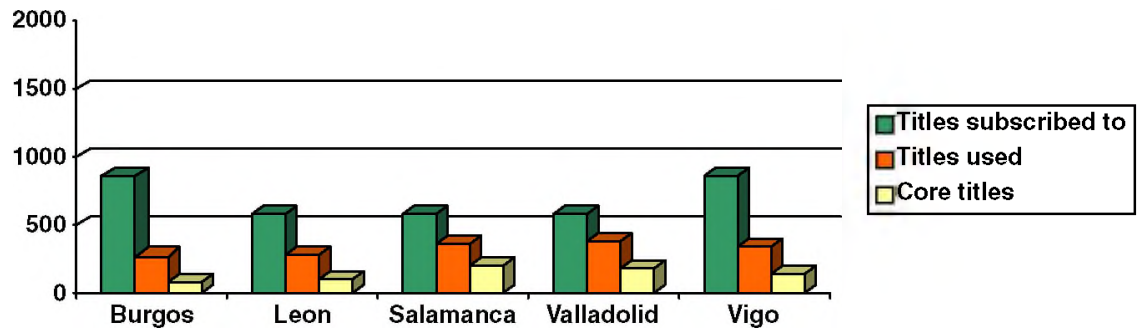

Figure 5. Titles from Wiley by university in 2006.

Table 10. SpringerLink

\begin{tabular}{|c|c|c|c|c|c|c|c|c|c|c|}
\hline & \multicolumn{2}{|l|}{ Burgos } & \multicolumn{2}{|l|}{ Leon } & \multicolumn{2}{|c|}{ Salamanca } & \multicolumn{2}{|c|}{ Valladolid } & \multicolumn{2}{|l|}{ Vigo } \\
\hline & 2006 & 2009 & 2006 & 2009 & 2006 & 2009 & 2006 & 2009 & 2006 & 2009 \\
\hline Titles subscribed to & 1,606 & 3,561 & 3,041 & 3,354 & 697 & 3,561 & - & 2,369 & 2,037 & 2,369 \\
\hline Titles used & 372 & 616 & 385 & 746 & 481 & 1,408 & - & 1,318 & 662 & 1,282 \\
\hline Core titles & 51 & 76 & 73 & 159 & 196 & 474 & - & 394 & 163 & 432 \\
\hline Dispersion rate & $23.16 \%$ & $17.29 \%$ & $12.66 \%$ & $22.24 \%$ & $69.01 \%$ & $39.53 \%$ & - & $55.63 \%$ & $32.49 \%$ & $54.11 \%$ \\
\hline Concentration rate & $13.70 \%$ & $12.33 \%$ & $18.96 \%$ & $21.31 \%$ & $40.74 \%$ & $33.66 \%$ & - & $29.89 \%$ & $24.62 \%$ & $33.69 \%$ \\
\hline
\end{tabular}

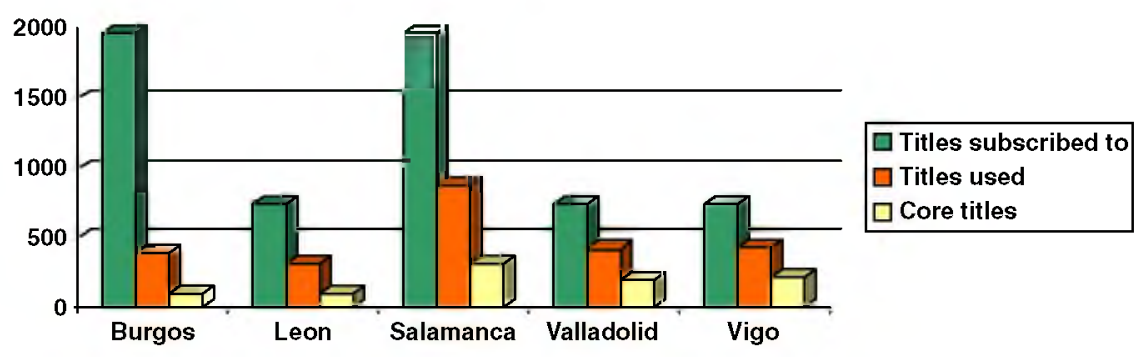

Figure 6. Titles from Wiley by university in 2009 .

Table 11. Wiley

\begin{tabular}{|c|c|c|c|c|c|c|c|c|c|c|}
\hline & \multicolumn{2}{|l|}{ Burgos } & \multicolumn{2}{|l|}{ Leon } & \multicolumn{2}{|c|}{ Salamanca } & \multicolumn{2}{|c|}{ Valladolid } & \multicolumn{2}{|l|}{ Vigo } \\
\hline & 2006 & 2009 & 2006 & 2009 & 2006 & 2009 & 2006 & 2009 & 2006 & 2009 \\
\hline Titles subscribed to & 860 & 1974 & 578 & 745 & 578 & 1974 & 578 & 745 & 861 & 745 \\
\hline Titles used & 270 & 397 & 279 & 322 & 369 & 871 & 386 & 420 & 337 & 428 \\
\hline Core titles & 71 & 98 & 92 & 102 & 192 & 318 & 176 & 199 & 148 & 210 \\
\hline Dispersion rate & $31.39 \%$ & $20.11 \%$ & $48.26 \%$ & $43.22 \%$ & $63.84 \%$ & $44.12 \%$ & $66.78 \%$ & $56.37 \%$ & $39.14 \%$ & $57.44 \%$ \\
\hline Concentration rate & $26.29 \%$ & $24.68 \%$ & $32.97 \%$ & $31.67 \%$ & $52.03 \%$ & $36.50 \%$ & $45.59 \%$ & $47.38 \%$ & $43.91 \%$ & $49.06 \%$ \\
\hline
\end{tabular}

period studied in all the universities. A percentage higher than 50 percent of the journals subscribed to from this package was used. For its part, the Emerald package showed more than half of the titles accessed in three of the universities and usage of nearly half in the other two. The universities of Valladolid and Vigo also used more than 50 percent of the titles they subscribed to in the SpringerLink and Wiley packages. The opposite extreme was the University of Burgos, the smallest institution analyzed, where the dispersion rates for these two providers did not reach 25 percent in 2009.

For the titles used with the greatest intensity, the concentration rate was higher in the three largest universities for all distributors. As happened with dispersion, the greatest concentration was also observed for the ScienceDirect package, which in 2009 at the University of Vigo exceeded 97 percent. The lowest intensity of use was seen at the University of Burgos, followed by the University of Leon. It was the usage of the SpringerLink package that had the lowest concentration rates in all the institutions studied.

\section{Financial Data}

The prices paid by the University of Leon corresponded to those assigned by the various providers, as was also the case for the price for Emerald at Vigo. Hence, these are not consortium purchase prices. In the Castile and Leon Autonomous Region, the BUCLE consortium negotiates joint prices with suppliers, although bills are paid individually by participating institutions.

The data from the University of Vigo relating to ScienceDirect, SpringerLink and Wiley corresponded to the payments assigned by the Bugalicia Consortium to the University of Vigo.

The prices paid for licenses were higher at the University of Vigo, being closer to those paid by Spanish university libraries in general, than to the amounts paid by the University of Leon. This 
Table 12. Emerald

\begin{tabular}{|c|c|c|c|c|}
\hline \multirow[t]{2}{*}{ University } & \multicolumn{2}{|l|}{2006} & \multicolumn{2}{|l|}{2009} \\
\hline & Leon & Vigo & Leon & Vigo \\
\hline Cost of package per journal subscribed to & $€ 6.64$ & $€ 63.19$ & $€ 6.07$ & $€ 153.14$ \\
\hline Cost of package per title used & $€ 10.80$ & $€ 94.54$ & $€ 12.56$ & $€ 285.30$ \\
\hline Cost of package per core title & $€ 41.48$ & $€ 243.93$ & $€ 50.87$ & $€ 757.34$ \\
\hline Cost of package per download & $€ 1.09$ & $€ 8.65$ & $€ 1.53$ & $€ 21.64$ \\
\hline Cost of package per 1000 students & $€ 66.61$ & $€ 469.01$ & $€ 138.62$ & $€ 2,011.40$ \\
\hline Cost of package per 100 academics & $€ 110.20$ & $€ 794.05$ & $€ 166.76$ & $€ 2,585.60$ \\
\hline
\end{tabular}

Table 13. ScienceDirect

\begin{tabular}{|c|c|c|c|c|}
\hline \multirow[t]{2}{*}{ University } & \multicolumn{2}{|l|}{2006} & \multicolumn{2}{|l|}{2009} \\
\hline & León & Vigo & León & Vigo \\
\hline Cost of package per journal subscribed to & $€ 4.05$ & $€ 140.57$ & $€ 28.71$ & $€ 147.76$ \\
\hline Cost of package per title used & $€ 6.20$ & $€ 182.79$ & $€ 44.43$ & $€ 206.29$ \\
\hline Cost of package per core title & $€ 11.91$ & $€ 321.31$ & $€ 92.10$ & $€ 211.36$ \\
\hline Cost of package per download & $€ 0.14$ & $€ 2.92$ & $€ 1.10$ & $€ 1.51$ \\
\hline Cost of package per 1000 students & $€ 631.15$ & $€ 9,946.39$ & $€ 5,770.99$ & $€ 17,452.94$ \\
\hline Cost of package per 100 academics & $€ 1,044.18$ & $€ 16,839.64$ & $€ 6,942.74$ & $€ 22,435.36$ \\
\hline
\end{tabular}

university benefited from a privileged situation that was the outcome of the limited number of institutional subscriptions in force at the moment when the university first took out contracts for the supply of electronic materials (Rodriguez et. al. ${ }^{49}$ ).

Yearly details for the relationship between the prices paid for subscriptions and the journals used and articles downloaded are given in tables 6 to 13 that are included in Appendix A. These figures are given in euros. ${ }^{6}$ With respect to the ratios for staff and students, these were calculated on the basis of the financial data for 2006 and 2009 and of the totals for the university populations in the academic years 2005-2006 and 2009-2010.

\section{Emerald}

In the case of the University of Leon, costs can be seen as advantageous. The amount per article downloaded was not high, even if slightly higher than the result for the other suppliers in 2007 and 2008 (see table 12). Regarding cost per title subscribed to, this was less than ten euro, with the amount spent on any of the titles that received some use not reaching twenty euro in any of the years investigated.

There was a very considerable increase in the cost of the subscription for Vigo from 2007 onward, with amounts that seem a long way from the sort of return on investment that might be expected. It must be kept in mind that downloads from Emerald were much less frequent than those from the other providers investigated because its contents are aimed at a group of potential users that is much smaller.

In both universities the license price remained stable over the final three years. The decrease in the price in 2009 was an outcome of the strength of the euro that year in comparison with the pound sterling $^{7}$ (Rodríguez and Olea ${ }^{50}$ ).

In respect of the costs of subscriptions relative to the academic population, the differences between the two universities grew. It

\footnotetext{
${ }^{6}$ The typical exchange rates for the euro in U.S. dollars, according to the data provided by the European Central Bank (http:/ www.ecb.int) were the following: 2005: US\$1.2441; 2006: US\$1.2556; 2007: US\$1.3705; 2008: US\$1.4708; 2009: US $\$ 1.3948$.

${ }^{7}$ The typical exchange rates for the euro in pounds sterling, according to the data provided by the European Central Bank (http://www.ecb.int) were the following: 2005: £0.68380; 2006: £0.68183; 2007: £0.68434; 2008: £0.79628; 2009: $£ 0.89094$.
}

should be pointed out that in 2009 the ratios at the University of Vigo were considerably higher than the ratios for costs found at the University of Leon.

\section{ScienceDirect}

At the University of Leon the price of subscribing to this collection increased extraordinarily over the final two years. It should be pointed out that the prices initially offered to this institution were unusually low, an outcome of the fact that the library of this university had barely any subscriptions to journals from the publisher Elsevier in its paper-format stocks. Such contracts as there were largely reflected personal subscriptions by individual staff members, which were not counted as part of the university's collections (see table 13).

The rise in the contract price, increasing five-fold between 2007 and 2009 , meant that the relative cost of titles and downloads had gone up considerably by 2009 . There was not such a jump in 2008 , thanks to the large number of downloads which occurred that year.

At the University of Vigo, prices for the subscription remained fairly stable over the five-year period studied. The increase seen in the number of downloads led to a more competitive cost-per-use ratio, especially in the final two years. This is reflected in the way that the relative costs for each article downloaded and for the titles composing the core tended to converge in the two universities.

In the two institutions, the cost per article downloaded both for journals used occasionally and for titles intensively used was attractive in all the years considered. This was relative to the price of a subscription to a journal in paper format or in comparison with the amounts paid for articles obtained through interlibrary loans, which will be further discussed below.

For this supplier the ratios of costs per student and per academic staff member came a little closer in 2009 than they were in 2006. However, they were some three times higher at the University of Vigo.

\section{SpringerLinls}

The price of the subscription rose roughly threefold between 2005 and the end of the period in both universities (see table 14). In the case of Leon, its total cost was much less than the amount paid for ScienceDirect, so that the relative cost for each download and each 
Table 14. SpringerLink

\begin{tabular}{|c|c|c|c|c|}
\hline \multirow[t]{2}{*}{ University } & \multicolumn{2}{|l|}{2006} & \multicolumn{2}{|l|}{2009} \\
\hline & León & Vigo & León & Vigo \\
\hline Cost of package per journal subscribed to & $€ 1.77$ & $€ 25.63$ & $€ 3.69$ & $€ 57.90$ \\
\hline Cost of package per title used & $€ 13.99$ & $€ 78.89$ & $€ 16.63$ & $€ 107.01$ \\
\hline Cost of package per core title & $€ 73.79$ & $€ 320.40$ & $€ 78.04$ & $€ 317.56$ \\
\hline Cost of package per download & $€ 1.75 €$ & $€ 6.31$ & $€ 1.68$ & $€ 6.13$ \\
\hline Cost of package per 1000 students & $€ 346.02$ & $€ 2,008.29$ & $€ 1,045.05$ & $€ 6,624.51$ \\
\hline Cost of package per 100 academics & $€ 572.46$ & $€ 3,400.11$ & $€ 1,257.23$ & $€ 8,515.69$ \\
\hline
\end{tabular}

title used was still within a competitive range, even though no great intensity of use was observed.

For the University of Vigo, the increase in the final three years was considerable. Although the use made of the package was greater than in Leon, the cost-per-use ratios moved significantly away from those in Leon, as did those for data from the ScienceDirect package in respect of downloads of articles. For both of the suppliers, however, the amount for the titles constituting the core during the period studied did converge to some extent.

At both universities the difference in the ratios of costs per member of the academic population remained stable from 2006 to 2009. The figures for the University of Vigo were some six times higher than those for the University of Leon.

\section{Wiley}

The price for the Wiley package remained stable from 2005 to 2009 (table 15). It fell into a range that would appear reasonable, to judge by the relative costs emerging from calculating price per use.

For the University of Vigo, data on the cost of the license were available only for the final two years, which, as in previous cases, showed great disparity with regard to the prices paid by Leon. In 2009 the differences in the ratios of cost per student and per academic staff member were considerable, and once more the University of Leon had the better deal.

The value per article downloaded was slightly lower than the cost of the SpringerLink package, while the value of the journals forming the core was higher.

To sum up, on the basis of the financial data available, it can be concluded that there is a disparity in the prices paid for access licenses by the universities of Leon and Vigo. The prices paid by Leon appear to constitute an exception due to the fact that they

Table 15. Wiley

\begin{tabular}{|c|c|c|c|}
\hline \multirow[t]{2}{*}{ University } & \multirow{2}{*}{$\frac{2006}{\text { León }}$} & \multicolumn{2}{|l|}{2009} \\
\hline & & León & Vigo \\
\hline Cost of package per journal subscribed to & $€ 10.80$ & $€ 7.83$ & $€ 142.57$ \\
\hline Cost of package per title used & $€ 22.39$ & $€ 18.12$ & $€ 248.18$ \\
\hline Cost of package per core title & $€ 67.91$ & $€ 57.21$ & $€ 505.81$ \\
\hline Cost of package per download & $€ 1.87$ & $€ 1.24$ & $€ 6.02$ \\
\hline Cost of package per 1000 students & $€ 401.32$ & $€ 491.50$ & $€ 5,129.21$ \\
\hline Cost of package per 100 academics & $€ 663.94$ & $€ 591.29$ & $€ 6,593.52$ \\
\hline
\end{tabular}

were based on the limited extent of previous holdings in paper format. The data from Vigo correspond to the result of an internal splitting of costs by the Bugalicia consortium; the outcome is that the ratios in Vigo are higher than in Leon, even though its level of consumption is likewise much higher (table 16).

At the University of Leon, the cost for titles that were intensively used showed good value for money from all four suppliers. Although it varied considerably in the five years studied, it in no case reached $€ 100$, an amount that is much lower than the average price of an individual journal subscription. The price of the ScienceDirect package was especially advantageous to Leon during the earlier years of its contract. As has been noted, from 2008 onward the price of subscribing to this package increased significantly. Hence, the cost relating to each title used in 2009 was higher than in the case of the other three providers, who had figures that were similar to each other.

For the University of Vigo, the prices for the titles forming the core lay for the most part between $€ 300$ and $€ 400$. These outlays would appear reasonable for scholarly journals. It was only in the case of Emerald in 2007, 2008 and 2009 that this range was exceeded, which raises a question about the return on investment for this access.

As was pointed out in the European Commission report ${ }^{51}$, over the past thirty years the prices of academic journals have grown steadily. Between 1975 and 1995 their prices rose by between 200 percent and 300 percent above inflation. Since the second date, the prices of journals have continued to increase at a rate greater than inflation, even if at a somewhat slower pace.

A good illustration is to be found in the figures provided on this topic by Rob Kling and Ewa Callahan, ${ }^{52}$ who pointed out that the journals Tetrahedron Letters and Brain Research already in the 1990 s cost more than $\$ 5,000$ yearly for an institutional subscription. A further example is the data from the University of Leon on journals distributed by Emerald. Hence, the Journal of Documentation during 2008, the last year in which the university had a subscription to the paper format, reached a price of $€ 964$, while the European Journal of Innovation Management cost $€ 729.54$ and Management Research: the Journal of The Iberoamerican Academy of Management had a price tag of $€ 320.37$ (table 17).

In view of the large number of downloads from ScienceDirect, the price for getting each individual article from this supplier was lower than was the case with the three others. The difference at the University of Vigo was more striking, while in Leon the cost

Table 16. Cost per title with more than 10 downloads

\begin{tabular}{|c|c|c|c|c|c|c|c|c|c|c|}
\hline & \multicolumn{2}{|l|}{2005} & \multicolumn{2}{|l|}{2006} & \multicolumn{2}{|l|}{2007} & \multicolumn{2}{|l|}{2008} & \multicolumn{2}{|l|}{2009} \\
\hline & Leon & Vigo & Leon & Vigo & Leon & Vigo & Leon & Vigo & Leon & Vigo \\
\hline Emerald & $€ 61.33$ & $€ 375.35$ & $€ 41.48$ & $€ 243.93$ & $€ 92.17$ & $€ 1,305.21$ & $€ 85.12$ & $€ 970.76$ & $€ 50.87$ & $€ 757.34$ \\
\hline ScienceDirect & $€ 13.31$ & $€ 385.99$ & $€ 11.91$ & $€ 321.31$ & $€ 16.70$ & $€ 365.27$ & $€ 37.19$ & $€ 311.72$ & $€ 92.10$ & $€ 211.36$ \\
\hline SpringerLink & $€ 65.30$ & $€ 397.33$ & $€ 73.79$ & $€ 320.40$ & $€ 43.54$ & $€ 484.61$ & $€ 53.11$ & $€ 362.18$ & $€ 78.04$ & $€ 317.56$ \\
\hline Wiley & $€ 56.16$ & - & $€ 67.91$ & - & $€ 68.55$ & - & $€ 50.75$ & $€ 431.04$ & $€ 57.21$ & $€ 505.81$ \\
\hline
\end{tabular}


Table 17. Cost per article downloaded

\begin{tabular}{|c|c|c|c|c|c|c|c|c|c|c|}
\hline & \multicolumn{2}{|l|}{2005} & \multicolumn{2}{|l|}{2006} & \multicolumn{2}{|l|}{2007} & \multicolumn{2}{|l|}{2008} & \multicolumn{2}{|l|}{2009} \\
\hline & Leon & Vigo & Leon & Vigo & Leon & Vigo & Leon & Vigo & Leon & Vigo \\
\hline Emerald & $€ 1.62$ & $€ 10.27$ & $€ 1.09$ & $€ 8.65$ & $€ 2.31$ & $€ 38.32$ & $€ 2.65$ & $€ 27.40$ & $€ 1.53$ & $€ 21.64$ \\
\hline ScienceDirect & $€ 0.15$ & $€ 3.55$ & $€ 0.14$ & $€ 2.92$ & $€ 0.19$ & $€ 3.24$ & $€ 0.46$ & $€ 2.12$ & $€ 1.10$ & $€ 1.51$ \\
\hline SpringerLink & $€ 1.34$ & $€ 8.74$ & $€ 1.75$ & $€ 6.31$ & $€ 0.90$ & $€ 9.50$ & $€ 0.94$ & $€ 6.89$ & $€ 1.68$ & $€ 6.13$ \\
\hline Wiley & $€ 1.23$ & - & $€ 1.87$ & - & $€ 1.58$ & - & $€ 1.19$ & $€ 5.11$ & $€ 1.24$ & $€ 6.02$ \\
\hline
\end{tabular}

showed a trend towards a nearly equal amount for all the suppliers in 2009.

In Vigo the costs per article downloaded from SpringerLink and Wiley tended to become similar and were significantly lower than the amount paid for Emerald. The data available for Salamanca (Lourdes Gutiérrez Palacios ${ }^{53}$ ) showed outlays falling into an intermediate range between the two universities studied here. That paper undertook an analysis of the use made in 2009 of electronic materials from ten sources, including journals, books and databases, yielding a cost per download of $€ 3.18$. The Bugalicia consortium report $(2010)^{54}$ found an average price per download of $€ 4.00$ in 2009 for all the electronic resources to which a subscription was held. The cost per article downloaded was $€ 3.96$, for ScienceDirect, $€ 8.67$ for SpringerLink and $€ 5.20$ for Wiley.

Similarly, the average prices per article downloaded stated by Boukacem-Zeghmouri ${ }^{55}$ can serve as an example. They found costs in 2005 of $€ 1.60$ in France, in the United States of $\$ 2.00$ and in the United Kingdom of $£ 1.50$. More recently, the CIBER report ${ }^{56}$, which studied the suppliers ScienceDirect and Oxford Journals in the United Kingdom during the academic year 2006-2007 at ten institutions undertaking research, found an average cost per download that came to $£ 0.80$.

It would appear that the returns on investment in electronic materials in the two universities under consideration is acceptable if the price of downloads is compared with the charges made by the Interlibrary Loans system in Spain. Thus, in the library network of the Spanish national research body CSIC, ${ }^{8}$ the price established in 2009 for the interlibrary loan of an article was $€ 23.23$. The price of an article obtained as an interlibrary loan through the grouping Rebiun (Academic Libraries Net), ${ }^{9}$ at the most recent rates set in 2010 is $€ 5$ per article up to forty copies, if obtained from another library in Rebiun.

The subscription to ScienceDirect is clearly worthwhile in both universities. In the case of the University of Vigo, despite the considerable amount paid for access to it, the user preference for this package leads to lower ratios than those relating to the other suppliers. In spite of the rather modest use made of the SpringerLink and Wiley packages, subscriptions to them also seem to be good value for money. If only the core journals are taken into account, the cost per title is advantageous, as is the value for each article downloaded, in relation to the tariffs for interlibrary loans in paid by Spanish libraries.

Subscriptions taken out under the Big Deal model have given good value for money by access to a much larger number of titles than previously available in paper form. This system has been positive as a starting point, as it has permitted real usage information to be recorded on the basis of access to very extensive generic collections. As Sanville pointed out a decade ago, ${ }^{57,58}$ it is necessary to find out what the real needs of users are in order to

\footnotetext{
${ }^{8}$ http://bibliotecas.csic.es/documents/valoracion_uso_bibliotecas.pdf.

${ }^{9}$ http://www.rebiun.org/pruebaConfig/reglamentos/tarifas.html.
}

shape the collection. The time has arrived when libraries can select the content that support user needs.

Nevertheless, the amounts spent by libraries for licenses giving access to electronic materials are considerable, as is noted at an international level. Richard Bleiler and Jill Livingston ${ }^{59}$ pointed out in the ARL report that in 2008-2009 university libraries spent more than 741 million dollars on electronic resources, while the CIBER study ${ }^{60}$ noted that the universities of the United Kingdom laid out 79.8 million pounds on licenses for access to electronic materials in the academic year 2006-2007 out of a total spend on journals of 100.12 million pounds. In Spain, expenditure on electronic resources by university libraries (Rebiun ${ }^{61}$ ) totaled 56.7 million euros. In the case of the data available from libraries in Castile and Leon, nearly half the budget was spent on the acquisition of electronic materials. At the University of Leon the figures were 42.39 percent in 2008 and 43.08 percent in 2009 , with the amount expended in 2009 being in excess of $€ 300,000$. Similarly, at the University of Salamanca, the percentage devoted to electronic resources reached 49.53 percent of the total library acquisitions budget in 2009 (Gutiérrez ${ }^{62}$ ).

Effective access to e-journals, as was noted by the European Commission report ${ }^{63}$, lies in the ability of libraries to continue paying the growing price of licenses. These costs are due to a growth in the totals of journals within packages, but also to the acquisition of backfiles; therefore, library budgets are under severe pressure to acquire current and archival content. Thus, moderation in price increases was advocated in the ICOLC recommendations, ${ }^{64}$ which requested publishers to hold prices steady in 2010-2011, so that users could maintain as many resources and licenses as possible. They also stressed the difficulties for budgeting that can arise for libraries from fluctuations in exchange rates.

\section{Conclusions}

The overall totals for downloads at the universities investigated showed constant growth from 2002 onward. Hence, there is clearly an upward trend in the consumption of scholarly information in electronic form in the Spanish academic communities studied, especially at the universities of Burgos and of Vigo. This climb in consumption is to be found in all the studies of usage that have been undertaken beyond those in Spain. For example, data presented by Sconul (2008) based on the use of e-journals at sixty-seven universities in the United Kingdom (CIBER ${ }^{65}$ ) indicated that downloads doubled in three years, with an annual growth rate of 21.7 percent between the academic years 2003-2004 and 2006-2007.

As to the providers investigated, throughout the decade ScienceDirect was the distributor preferred by all five universities studied. Its percentages of downloads were over 80 percent of the total for the 2009 in four of these institutions. Hence, this is an essential supplier for the universities analyzed, a situation that may be generalized to the international academic community as a whole. 
From the comparative figures per student and per academic staff member, the use of electronic content overall in the two largest universities under consideration was lower than was the case in the smaller institutions, this being especially noteworthy at the University of Vigo. Also, there is a relationship between the degree programs offered and the use of certain content, as happened with the Emerald package at the University of Burgos. As for the ratios for students, it must be kept in mind that there was a generalized decline in student numbers between 2006 and 2009, which must have had an impact on the increase in ratios that was noted and which means that these data should be taken with some caution. However, it does seem that the growth in the ratios of downloads per 100 academic staff are reliable and consistent, since the number of such staff varied only very slightly in all the universities and this group constitutes the prime users of electronic journals.

The considerable dispersion in the use of contents from ScienceDirect was striking. A somewhat similar pattern could be noted for Emerald because of the small size of the package offered. Finally, in 2009 Valladolid and Vigo used more than 50 percent of the titles offered by SpringerLink and Wiley.

Most downloads were of a limited proportion of titles. This tendency has been confirmed since the very beginning of the utilization of e-journals. It was noted by Eason, Richardson and $\mathrm{Yu},{ }^{66}$ Davis, ${ }^{67}$ and the more recent work by Nicholas and the CIBER research group, who stated that the majority of users restrict themselves to exploring between one and three journals (Nicholas and Huntington ${ }^{68}$ ).

Conclusions about profitability will need to be nuanced in further studies investigating that aspect, which hitherto has received little attention. In any case, as the study performed for the European Commission pointed out, ${ }^{69}$ the price of electronic access should not depend on the number of print-format subscriptions previously held; it should be based on transparent indicators, such as usage statistics or the number of academic staff or of students, or the like. This pricing method is what JSTOR utilizes by distinguishing between very large, large, medium, small and very small institutions.

Members of consortia vary in their programs and user needs. Some prefer complete collections, while others like to concentrate on given sub-disciplines. In view of this situation, Davis ${ }^{70}$ suggested using criteria other than mere geography when setting up consortia by taking into account the size of institutions and the disciplines in which they specialize. Thanks to usage statistics, the identification of the real interests of the various academic communities leads to the conclusion that "à la carte" would be the route to take over the coming years, as stressed by the ICOLC declarations ${ }^{71}$ This approach is all the more essential in a period of crisis and budget restrictions. The coalition of consortia requested flexibility on the part of providers so that libraries would not be obliged to cancel materials nor create gaps in collections.

Made-to-measure supply (create one's own collections) was also pointed to in the study undertaken for the European Commission, ${ }^{72}$ in which it was suggested that libraries ought to have the possibility of choosing groups of publications and making up their own bundles of electronic materials. Similarly, the journals selected should each have their individual price and that charges for bundles should be made known, which would avoid the variations in circumstances which were observed in this study to apply to the universities of Leon and Vigo.

Although current contracts do not permit sufficient flexibility to enable such an individualized selection, there would not appear to be any technical limitations preventing "à la carte" agreements, allowing libraries to select and make to measure their own packages of electronic materials. Prices could be set for packages of different sizes in accordance with transparent criteria.

In conclusion, it is possible to give a positive, data-driven assessment of the Big Deal model for access to electronic information, above all because of the flexibility of use that it encourages. The large range of content and great ease of access create more user consumption. The benefits of purchase through this system have been particularly significant for small and medium universities. However, libraries need to regain their capacity for individual, customized selections. At the moment, library collections are clones of each other, while the preferences of the research communities at different universities are varied. On this point, usage and return on investment data are essential tools for management and decision making.

Finally, a future project of considerable interest is to learn the value of investment in electronic materials with respect to the productivity of researchers. This implies the rate of return in the form of visibility for the University.

\section{Appendix A}

Table 1. Overall downloads of articles by institution and by year

\begin{tabular}{llllllll}
\hline University & $\mathbf{2 0 0 2}$ & $\mathbf{2 0 0 3}$ & $\mathbf{2 0 0 4}$ & $\mathbf{2 0 0 5}$ & $\mathbf{2 0 0 6}$ & $\mathbf{2 0 0 7}$ & $\mathbf{2 0 0 9}$ \\
\hline Burgos & 12,063 & 4,723 & 22,171 & 28,218 & 42,274 & 46,741 & 57,452 \\
Leon & - & 51,313 & 52,866 & 70,337 & 74,166 & 81,128 & 126,107 \\
Salamanca & - & - & - & - & 147,016 & 75,437 \\
Valladolid & 34,054 & 57,858 & 79,864 & 110,152 & - & 125,380 & 138,162 \\
Vigo & - & - & 61,582 & 93,283 & 107,848 & 134,308 & 125,616 \\
\hline
\end{tabular}

Table 2. Total downloads from Emerald by year

\begin{tabular}{|c|c|c|c|c|c|c|c|c|}
\hline University & 2002 & 2003 & 2004 & 2005 & 2006 & 2007 & 2008 & 2009 \\
\hline Burgos & 230 & 355 & 396 & 443 & 1,186 & 1,709 & 1,485 & 1,106 \\
\hline Leon & - & 640 & 368 & 567 & 948 & 914 & 770 & 1,071 \\
\hline Salamanca & - & - & - & - & 2,356 & 2,474 & 1,808 & 1,148 \\
\hline Valladolid & 1,046 & 1,153 & 1,731 & 1,000 & 2,276 & 1,679 & 1,245 & 1,513 \\
\hline Vigo & - & 641 & 559 & 950 & 1,409 & 1,294 & 1,771 & 1,924 \\
\hline
\end{tabular}


Table 3. Total downloads from ScienceDirect by year

\begin{tabular}{|c|c|c|c|c|c|c|c|c|}
\hline University & 2002 & 2003 & 2004 & 2005 & 2006 & 2007 & 2008 & 2009 \\
\hline Burgos & 9,222 & - & 17,340 & 22,008 & 32,590 & 35,053 & 46,493 & 48,417 \\
\hline Leon & - & 46,018 & 46,210 & 62,658 & 66,825 & 68,491 & 110,027 & 62,121 \\
\hline Salamanca & - & - & - & - & 118,331 & 86,785 & 96,747 & 93,154 \\
\hline Valladolid & 30,444 & 54,945 & 74,643 & 101,954 & 120,703 & 112,825 & 126,065 & 144,433 \\
\hline Vigo & - & - & 51,110 & 77,552 & 88,538 & 100,066 & 161,414 & 239,325 \\
\hline
\end{tabular}

Table 4. Total downloads from SpringerLink by year

\begin{tabular}{|c|c|c|c|c|c|c|c|c|}
\hline University & 2002 & 2003 & 2004 & 2005 & 2006 & 2007 & 2008 & 2009 \\
\hline Burgos & 838 & 505 & 840 & 1,330 & 2,152 & 3,151 & 3,375 & 3,700 \\
\hline Leon & 2,023 & 989 & 2,494 & 2,962 & $3,063^{\mathrm{a}}$ & 7,651 & 10,381 & 7,349 \\
\hline Salamanca & - & - & - & - & 9,241 & 18,606 & 21,128 & 20,932 \\
\hline Vigo & - & - & 3,829 & 5,631 & 8,276 & 12,640 & 18,897 & 22,350 \\
\hline
\end{tabular}

a Data for January through June.

Table 5. Total downloads from Wiley by year

\begin{tabular}{|c|c|c|c|c|c|c|c|c|}
\hline University & 2002 & 2003 & 2004 & 2005 & 2006 & 2007 & 2008 & 2009 \\
\hline Burgos & 1,773 & 3,863 & 3,595 & 4,437 & 6,346 & 6,828 & 6,099 & 6,214 \\
\hline Leon & - & 3,666 & 3,794 & 4,150 & 3,330 & 4,072 & 4,929 & 4,682 \\
\hline Salamanca & - & - & - & - & 17,088 & 17,515 & 18,479 & 22,270 \\
\hline Valladolid & - & - & - & - & 12,461 & 10,323 & 11,244 & 12,422 \\
\hline Vigo & - & - & 6,084 & 9,150 & 9,625 & 11,616 & 16,772 & 17,623 \\
\hline
\end{tabular}

Table 6. Financial data Emerald University of Leon

\begin{tabular}{|c|c|c|c|c|c|}
\hline & 2005 & 2006 & 2007 & 2008 & 2009 \\
\hline Cost of package per journal subscribed to & $€ 7.41$ & $€ 6.64$ & $€ 8.76$ & $€ 8.40$ & $€ 6.07$ \\
\hline Cost of package per title used & $€ 10.57$ & $€ 10.80$ & $€ 18.12$ & $€ 17.31$ & $€ 12.56$ \\
\hline Cost of package per core title & $€ 61.33$ & $€ 41.48$ & $€ 92.17$ & $€ 85.12$ & $€ 50.87$ \\
\hline Cost of package per download & $€ 1.62$ & $€ 1.09$ & $€ 2.31$ & $€ 2.65$ & $€ 1.53$ \\
\hline
\end{tabular}

Table 7. Financial data Emerald University of Vigo

\begin{tabular}{|c|c|c|c|c|c|}
\hline & 2005 & 2006 & 2007 & 2008 & 2009 \\
\hline Cost of package per journal subscribed to & $€ 72.82$ & $€ 63.19$ & $€ 227.51$ & $€ 191.85$ & $€ 153.14$ \\
\hline Cost of package per title used & $€ 84.13$ & $€ 94.54$ & $€ 381.52$ & $€ 321.44$ & $€ 285.30$ \\
\hline Cost of package per core title & $€ 375.35$ & $€ 243.93$ & $€ 1,305.21$ & $€ 970.76$ & $€ 757.34$ \\
\hline Cost of package per download & $€ 10.27$ & $€ 8.65$ & $€ 38.32$ & $€ 27.40$ & $€ 21.64$ \\
\hline
\end{tabular}

Table 8. Financial data ScienceDirect University of Leon

\begin{tabular}{lllll}
\hline & $\mathbf{2 0 0 5}$ & $\mathbf{2 0 0 6}$ & $\mathbf{2 0 0 7}$ & $\mathbf{2 0 0 9}$ \\
\hline Cost of package per journal subscribed to & $€ 4.54$ & $€ 4.05$ & $€ 5.65$ & $€ 2.36$ \\
Cost of package per title used & $€ 6.87$ & $€ 6.20$ & $€ 8.25$ & $€ 28.71$ \\
Cost of package per core title & $€ 13.31$ & $€ 11.91$ & $€ 16.70$ & $€ 4.43$ \\
Cost of package per download & $€ 0.15$ & $€ 0.14$ & $€ 0.19$ & $€ 92.10$ \\
\hline
\end{tabular}

Table 9. Financial data ScienceDirect University of Vigo

\begin{tabular}{|c|c|c|c|c|c|}
\hline & 2005 & 2006 & 2007 & 2008 & 2009 \\
\hline Cost of package per journal subscribed to & $€ 128.48$ & $€ 140.57$ & $€ 177.35$ & $€ 144.49$ & $€ 147.76$ \\
\hline Cost of package per title used & $€ 200.13$ & $€ 182.79$ & $€ 218.37$ & $€ 207.37$ & $€ 206.29$ \\
\hline Cost of package per core title & $€ 385.99$ & $€ 321.31$ & $€ 365.27$ & $€ 311.72$ & $€ 211.36$ \\
\hline Cost of package per download & $€ 3.55$ & $€ 2.92$ & $€ 3.24$ & $€ 2.12$ & $€ 1.51$ \\
\hline
\end{tabular}


Table 10. Financial data SpringerLink University of Leon

\begin{tabular}{|c|c|c|c|c|c|}
\hline & 2005 & 2006 & 2007 & 2008 & 2009 \\
\hline Cost of package per journal subscribed to & $€ 2.55$ & $€ 1.77$ & $€ 2.06$ & $€ 2.92$ & $€ 3.69$ \\
\hline Cost of package per title used & $€ 15.55$ & $€ 13.99$ & $€ 10.18$ & $€ 11.99$ & $€ 16.63$ \\
\hline Cost of package per core title & $€ 65.30$ & $€ 73.79$ & $€ 43.54$ & $€ 53.11$ & $€ 78.04$ \\
\hline
\end{tabular}

Table 11. Financial data SpringerLink University of Vigo

\begin{tabular}{lllll}
\hline & $\mathbf{2 0 0 5}$ & $\mathbf{2 0 0 6}$ & $\mathbf{2 0 0 7}$ & $\mathbf{2 0 0 9}$ \\
\hline Cost of package per journal subscribed to & $€ 71.92$ & $€ 25.63$ & $€ 59.00$ & $€ 57.90$ \\
Cost of package per title used & $€ 133.88$ & $€ 78.89$ & $€ 135.64$ & $€ 59.05$ \\
Cost of package per core title & $€ 397.33$ & $€ 320.40$ & $€ 484.61$ & $€ 120.84$ \\
Cost of package per download & $€ 8.74$ & $€ 6.31$ & $€ 9.50$ & $€ 317.56$ \\
\hline
\end{tabular}

Table 12. Financial data Wiley University of Leon

\begin{tabular}{|c|c|c|c|c|c|}
\hline & 2005 & 2006 & 2007 & 2008 & 2009 \\
\hline Cost of package per journal subscribed to & $€ 7.61$ & $€ 10.80$ & $€ 10.70$ & $€ 8.53$ & $€ 7.83$ \\
\hline Cost of package per title used & $€ 15.82$ & $€ 22.39$ & $€ 22.93$ & $€ 18.63$ & $€ 18.12$ \\
\hline Cost of package per core title & $€ 56.16$ & $€ 67.91$ & $€ 68.55$ & $€ 50.75$ & $€ 57.21$ \\
\hline Cost of package per download & $€ 1.23$ & $€ 1.87$ & $€ 1.58$ & $€ 1.19$ & $€ 1.24$ \\
\hline
\end{tabular}

Table 13. Financial data Wiley University of Vigo

\begin{tabular}{lll}
\hline & $\mathbf{2 0 0 8}$ & $\mathbf{2 0 0 9}$ \\
\hline Cost of package per journal taken & $€ 124.67$ & $€ 142.57$ \\
Cost of package per title used & $€ 204.23$ \\
Cost of package per core title & $€ 431.04$ \\
Cost of package per download & $€ 5.11$ & $€ 505.81$ \\
\hline
\end{tabular}

\section{Notes}

1. Ken Eason, Sue Richardson and Liangzhi Yu, "Patterns of use of electronic journals," Journal of Documentation 56, no. 5 (2000): 477-504.

2. Blanca Rodríguez Bravo and María Luisa Alvite Díez, "Análisis de los contenidos distribuidos por proveedores de publicaciones electrónicas," $E$ Profesional de la Información 13, no. 6 (2004): 441-49.

3. Blanca Rodríguez Bravo and María Luisa Alvite Díez, "Survey of the Providers of Electronic Publications Holding Contracts with Spanish University Libraries," D-Lib Magazine 11, no. 4 (2005) http://www.dlib.org/dlib/ april05/alvite/04alvite.html (accessed January 27, 2011).

4. María Luisa Alvite Dỉez and Blanca Rodríguez Bravo, "Distribuidores de contenidos electrónicos: acceso, interfaz y funcionalidades," in 9as. Jornadas Españolas de Documentación (Madrid: Fesabid, 2005), 29-46.

5. Carol Tenopir, Use and Users of Electronic Library Resources: An Overview and Analysis of Recent Research Studies (Washington, D.C.: Council on Library and Information Resources, 2003). http:/www.clir.org/pubs/reports/pub120/ pub120.pdf (accessed January 25, 2011)

6. Ian Rowlands, "Electronic journals and user behavior: a review of recent reseatch," Library and Information Science Research 29, no. 3 (2007): 369-96.

7. Ingenta Institute, The Consortium Site Licence: is it a sustainable model? Edited Proceedings of a Meeting Held on 24 September 2002, London, Organised by the Ingenta Institute (Oxford: Ingenta Institute, 2002).

8. David Baker, "Inside every fat man: balancing the digital library budget," Interlending and Document Supply 36, no. 4 (2008): 213-17.

9. David Ball, "What's the "Big Deal", and why is it a Bad Deal for universities?" Interlending and Document Supply 32, no. 2 (2004): 117-125.

10. Ángel Borrego (dir.), Estudi d'usuaris de les revistes electròniques del CBUC. Consorci de Biblioteques Universitaries de Catalunya (2005), http:/www.recercat.net bitstream/2072/1439/1/ESTUDI+USUARIS.pdf (accessed January 27, 2011).

11. Kenneth Frazier, "The Librarian's Dilemma: Contemplating the Costs of the Big Deal," D-Lib Magazine 7, no. 3 (2001) http://www.dlib.org/dlib/march01/ frazier/03frazier.html (accessed January 26, 2011).
12. Kenneth Frazier, "To the Editor: letters in response to the opinion piece, The Librarian's Dilemma: Contemplating the Costs of the Big Deal," D-Lib magazine 7, no. 4 (2001) htt://www.dlib.org/dlib/april01/04letters.html (accessed January 26,2011 ).

13. David Nicholas and Paul Huntington, "Electronic journals: are they used?" Interlending and Document Supply 34, no. 2 (2006): 74-7.

14. Mark Rowse, "The Consortium Site License: a sustainable model?" Libri 53, no. 1 (2003): $1-10$.

15. Thomas J. Sanville, "Method out of the madness: Ohiolink's collaborative response to the serial crisis four years later: a progress report," Serials 14, no. 2 (2001): 163-177.

16. Thomas J. Sanville, "T. A. method out of the madness: Ohiolink's collaborative response to the serial crisis three years later: a progress report," The Serials Librarian 40, no. 1/2 (2001): 129-155.

17. Cristóbal Urbano, et al., "The Use of Consortially Purchased Electronic Journals by the CBUC (2000-2003)," D-Lib Magazine 10, no. 6 (2004) http://www.dlib.org/ dlib/june04/anglada/06anglada.html (accessed January 22, 2011),

18. Sanville, "Method out of the madness."

19. Thomas A. Peters, "What's the use? The value of e-Resource usage statistics," New Library World 103, no. 1172/1173 (2002): 39-47.

20. Eason, Richardson and Yu, "Patterns of use of electronic journals."

21 Ken Eason, Liangzhi Yu and Susan Harker, "The use and usefulness of functions in electronic journals: the experience of the Superjournal Project," Program 34, no. 1 (2000): 1-28.

22. Philip M. Davis, "Patterns in electronic journal usage: challenging the composition of geographic consortia," College \& Research Libraries (November 2002): 484-97.

23. Philip M. Davis, "Information-seeking behavior of chemists: a transaction log analysis of referral URLs," Joumal of the American Society for Information Science and Technology 55, no. 4 (2004): 326-332.

24. Philip M. Davis, "For electronic journals, total downloads can predict number of users," Portal: Libraries and the Academy 4, no. 3 (2004): 379-92. 
25. Philip M. Davis and Leah R. Solla, "An IP-level analysis of usage statistics for electronic joumals in chemistry: making inferences about user behavior," Joumal of the American Society for Information Science and Technology 54, no. 11 (2003): $1062-68$.

26. Philip M. Davis and Jason S. Price, "e-journal interface can influence usage statistics: implications for libraries, publishers, and project COUNTER," Ioumal of the American Society for Information Science and Technology 57, no. 9 (2006): $1243-48$.

27. Marisa Scigliano, "Measuring the use of networked electronic journals in an Academic Library Consortium: moving beyond MINES for Libraries in Ontario Scholar's Portal," Serials Review 36, no. 2 (2010): 72-8.

28. Paul Huntington, David Nicholas, Hamid R. Jamali and Carol Tenopir, "Article decay in the digital environment: an analysis of usage of Ohiolink by date of publication, employing deep log methods," Journal of the American Society for Information Science and Technology 57, no. 13 (2006): 1840-51.

29. David Nicholas, Paul Huntington, Hamid R. Jamali and Carol Tenopir, "What deep log analysis tells us about the impact of Big Deals: case study OhioLINK," Journal of Documentation 62, no. 4 (2006): 482-508.

30. David Nicholas, Paul Huntington and Hamid R. Jamali, "User diversity as demonstrated by deep log analysis," The Electronic Library 26, no. 1 (2008): 21-38.

31. David Nicholas, Paul Huntington, Hamid R. Jamali, Ian Rowlands and Carol Tenopir, "Viewing and reading behaviour in a virtual environment: the fulltext download and what can be read into it," Aslib Proceedings 60, no. 3 (2008): 185-98.

32. Carol Tenopir, Donald W. King, Sheri Edwards and Lei Wu, "Electronic journals and changes in scholarly article seeking and reading patterns," Aslib Proceedings 61, no. 1 (2009): 5-32.

33. Paola Gargiulo, "Electronic journals and users: the CIBER experience in Italy," Serials: The lournal for the Serials Community 6, no. 3 (2003): 293-98.

34. Joseph Frank Rogani, "Library consortia and digital services: users' perceptions at the University of Calabria," New Library World 8, no. 11/12 (2007): 504-25.

35. Cherifa Boukacem-Zeghmouri and Joachim Schopfel, "On the usage of eJournals in French universities," Serials: The Journal for the Serials Community 21, no. 2 (2008): 121-26.

36. Ángel Borrego and Cristóbal Urbano, "Analysis of the behaviour of the users of a package of electronic journals in the field of chemistry," Joumal of Documentation 63, no. 2 (2007): 243-258.

37. Ángel Borrego, Lluís Anglada, Maite Barrios and Núria Comellas, "Use and users of electronic journals at Catalan universities: the results of a survey," Journal of Academic Librarianship 33, no. 1 (2007): 67-75.

38. Blanca Rodríguez Bravo, María Luisa Alvite Díez, Leticia Barrionuevo Almuzara and María Antonia Morán Suárez, "Patterns of use of electronic journals in Spanish university libraries," Serials Review 34, no. 2 (2008): 115-28.

39. Miquel Termens, "Looking below the surface: the use of electronic journals by the members of a library consortium," Library Collections, Acquisitions, and Technical Services 32, no. 2 (2008): 76-85.

40. Candela Ollè and Ángel Borrego, "Librarians' perceptions on the use of electronic resources at Catalan Academic Libraries: results of a focus group," New Library World 111, no. 172 (2010): 46-54(preprint)

41. Sanville, "Method out of the madness."

42. Ibid.

43. Bugalicia: Consorcio de bibliotecas universitarias de Galicia, Estudos de BUGalicia. http://w3b.bugalicia.org/index.php?option $=$ com_content\&view $=$ atticle\&id=21\&Itemid $=21$ (accessed January 22, 2011).

44. Lluis Anglada, Nuria Comellas, Joana Roig, Ramón Ros and Marta Tort, "Licensing, organizing and accessing e-Journals in the Catalan university libraries," Serials: The Journal for the Serials Community 16, no. 3 (2003): 299-306.

45. Borrego, Estudi d'usuaris de les revistes electròniques del CBUC.
46. Boukacem-Zeghmouri Schopfel, "On the usage of e-Journals in French universities."

47. CIBER: Centre for Information Behaviour and the Evaluation of Research, EJournals: Their Use, Value and Impact (London: London City University, 2009) wwww.rin.ac.uk/system/files/attachments/E-journals-report.pdf (accessed January 22, 2011).

48. Rodríguez Bravo, "Patterns of use of electronic journals."

49. Blanca Rodríguez Bravo et. al., "La rentabilidad de la información electrónica. Análisis del uso de suministradores multidisciplinares en la Universidad de Leôn", in 12as Jomadas Españolas de Documentación (Málaga: Fesabid, 2011) (in press), p. 75-76.

50. Blanca Rodríguez Bravo and Isabel Olea, "La rentabilidad de las revistas electrónicas. El caso de Emerald en la universidad de León," in XII Jornadas de Gestión de la información. Valor económico de la información: mercados, servicios y rentabilidad (Madrid: SEDIC, 2010) http://eprints.rclis.org/handle/ 10760/12010 (accessed January 25, 2011).

51. European Commission, Study on the Economic and Technical Evolution of the Scientific Publication Market in Europe (2006) http://ec.europa.eu/research/ science-society/pdf/scientific-publication-study_en.pdf (accessed January 22, 2011).

52 Rob Kling and Ewa Callahan, "E. Electronic Journals, the Internet, and scholarly communication," Annual Review of Information Science and Technology 37 (2003): 127-77.

53 Lourdes Gutiérrez Palacios, "Análisis de las colecciones digitales mediante una aplicación informática específica: la experiencia de la Universidad de Salamanca," in XWorkshop Rebiun, Proyectos digitales. Diez años de proyectos digitales. Cambian las bibliotecas, cambian los profesionales (Valencia, 2010) http://riunet.upv.es/ manalkin/handle/10251/8675 (accessed January 23, 2011).

54 Bugalicia: Consorcio de bibliotecas universitarias de Galicia, Estudo da "rendibilidade" das coleccións de revistas electrónicas presentes na colección de Bugalicia do 2006 ao 2009 (2010) http://www.bugalicia.org/ (accessed January $22,2011)$.

55. Zeghmouri and Schopfel, "On the usage of e-Journals in French universities."

56. CIBER, E-journals: their use, value and impact.

57. Sanville, "Method out of the madness."

58. Ibid.

59. Richard Bleiler and Jill Livingston, SPEC Kit 316: Evaluating E-resources (Washington: ARL, Association of Research Libraries, 2010).

60. CIBER, E-journals: their use, value and impact.

61. Rebiun: Red de Bibliotecas Universitarias, Memoria anual 2008. http:/www. rebiun.org/handle404?exporturi =/export/docReb/memoriaRebiun2008.pdf (accessed January 23, 2011).

62. Gutiérrez Palacios, "Análisis de las colecciones digitales."

63. European Commission, Study on the Economic and Technical Evolution.

64. ICOLC: International Coalition of Library Consortia, Statement on the Global Economic Crisis and its Impact on Consortial Licenses. 2010. http://www library. yale.edu/consortia/icolc-econcrisis-0610.htm (accessed January 27, 2011).

65. CIBER, E-journals: their use, value and impact, 15.

66. Eason, Richardson, Yu, "Patterns of use of electronic journals."

67. Davis, "Patterns in electronic journal usage."

68. Nicholas, Huntington, "Electronic journals: are they used?"

69. European Commission, Study on the Economic and Technical Evolution.

70. Davis, "Patterns in electronic journal usage."

71. ICOLC, Statement on the Global Economic Crisis.

72. European Commission, Study on the Economic and Technical Evolution. 